\title{
Review
}

Iqra Aroob\#, Nasir Ahmad", Naeem Rashid*

\section{Cyclodextrin-preferring glycoside hydrolases: properties and applications}

https://doi.org//10.1515/amylase-2021-0003

Received March 31, 2021; accepted May 19, 2021.

\begin{abstract}
Cyclodextrin-hydrolyzing enzymes are widespread in bacteria and archaea where they play their roles in carbohydrates metabolism. They were previously characterized as cyclodextrinases, neopullulanases and maltogenic amylases. In the Carbohydrate-Active enZyme (CAZy) database, most of these enzymes are grouped into the GH13_20 subfamily of the $\alpha$-amylase family GH13. Here, we have summarized the information available on the substrate specificity, structural features, physiological roles and applications of cyclodextrin-preferring glycoside hydrolases. These enzymes form a distinct group in the $\alpha$-amylase family. Members of this distinct group possess an extra extension at the N-terminus, which causes a modification of the active site geometry thus making these enzymes more specific for smaller molecules like cyclodextrins than for macromolecules such as starches or pullulan. Multi-substrate specificity, hydrolytic as well as transglycosylation activities make these enzymes attractive for applications in the food and pharmaceutical industries. We have tried here to collect information available on their biochemical properties, three-dimensional structures, physiological roles and potential applications.
\end{abstract}

Keywords: cyclodextrinases; structures; properties; applications.

\section{Abbreviations}

$\mathrm{CD}$, cyclodextrin; CDase, cyclomaltodextrinase; GH, glycoside hydrolase; MAase, maltogenic amylase; NPase, neopullulanase; ThMA; maltogenic amylase from Thermus sp. IM6501.

*Corresponding author: Naeem Rashid, University of the Punjab, Lahore, Punjab, Pakistan, E-mail: naeemrashid37@hotmail.com Iqra Aroob, Nasir Ahmad, School of Biological Sciences, University of the Punjab, Lahore, Punjab, Pakistan

\#Authors contributed equally and, in their opinion, should be considered as joint first author

\section{Introduction}

Cyclodextrins (CDs) refer to cyclic oligo-glucosides joined via $\alpha-1,4-$ glycosidic linkages. Depending upon the number of D-glucopyranosyl residues, that may be six, seven or eight, CDs are termed as $\alpha$-, $\beta$ - or $\gamma-C D$, respectively. Most of the CD-hydrolyzing enzymes characterized to date belong to subfamily 20 of the glycoside hydrolase (GH) family 13 [1] (http://www.cazy.org/GH13_20.html). Initially, cyclomaltodextrinases (CDases; EC 3.2.1.54), maltogenic amylases (MAases; EC 3.2.1.133) and neopullulanases (NPases; EC 3.2.1.135) were included in this distinct group [1]. CDases are the enzymes that preferentially hydrolyze CDs, MAases are the enzymes that favor to generate maltose from hydrolysis of starch, and NPases are the enzymes that are capable of hydrolyzing pullulan into panose. Members of this distinct group catalyze all the three reactions, however, they prefer CDs over starch and pullulan, and are involved in intracellular processing of CDs [2,3]. With further advancements in structural biology, it was found that these three classes of enzymes were not very much different from each other. It was hence proposed that CDases, MAases and NPases are nearly the same enzymes in terms of structure and catalytic characteristics, therefore they should be classified under the same name and enzyme code. CDase was proposed as the best name for them $[3,4]$.

The first report on CD-hydrolyzing enzyme was published in 1968 with the identification and pattern of action of a CDase from Bacillus macerans [5,6]. Afterwards, CDases from various sources, such as Bacillus coagulans [7], Clostridium thermohydrosulfuricum [8], alkalophilic Bacillus sp. [9], Bacillus sphaericus E-244 [10-12], Bacillus sp. I-5 [13], Bacillus subtilis SUH4-2 [14], Flavobacterium sp. [15], Bacillus sphaericus ATCC7055 [16], Bacillus clarkii [17], Bacillus sp. US149 [18], Geobacillus caldoxylosilyticus TK4 [19], Massilia timonae [20], Bacillus subtilis WPD616 [21], Geobacillus thermopakistaniensis [22] and several others were characterized from bacterial sources. Enzymes of archaeal origin were characterized from Thermococcus sp. strain B1001 [23], Thermococcus sp. CL1 [24], Thermococcus 
kodakarensis KOD1 [25,26], Thermofilum pendens [27], Pyrococcus furiosus [28], Thermoplasma volcanium GSS1 [29], Staphylothermus marinus [30] and Palaeococcus pacificus [31].

\section{Biochemical properties of CDases}

\subsection{Cyclodextrin preference}

Most of the CDases cleave $\alpha-1,4$-glucosidic linkages, however, a few of them, including the enzyme from Lactobacillus gasseri ATCC 33323, also hydrolyze $\alpha-1,6$ glucosidic linkages. Ring-opening of CDs is the ratelimiting step, once the ring opens, it is processed, by CDases, similar to linear oligosaccharides [32]. CDases are multi-substrate hydrolyzing enzymes. Usually, they prefer either $\alpha$-, $\beta$ - or $\gamma$-CD.

$\alpha$-CD-preferring CDases include enzymes from Clostridium thermohydrosulfuricum 39E [33], Bacillus stearothermophilus HY-1 [34], Geobacillus thermopakistaniensis [22], Geobacillus sp. Gh6 [35], Palaeococcus pacificus [31], Pyrococcus furiosus [28], Anoxybacillus flavithermus ZNU-NGA [36] and a CDase expressed from environmental DNA isolated directly from a hot spring in Thailand [37]. CDases characterized from Massilia timonae [20], Paenibacillus sp. A11 [38, 39], Alicyclobacillus acidocaldarius [40], Thermococcus. sp. strain B1001 [23], Thermococcus kodakarensis [25], Laceyella sp. [41], and Bacillus sphaericus ATCC7055 [16] prefer $\beta$-CD. The CDases from Thermofilum pendens [27] and Bacillus clarkii [17] are among the $\gamma$-CD-preferring enzymes.

The CDases that show a slightly higher preference for maltooligosaccharides include enzymes from Flavobacterium sp., Pyrococcus furiosus and Bacillus coagulans [7, 5,42]. Similarly, a CDase characterized (after heterologous expression of metagenome DNA) from cow rumen showed preference for maltooligosaccharides as compared with CDs [43]. A CDase from Lactobacillus plantarum exhibited almost equal activity against $\beta-C D$ and starch [44]. Table 1 gives a detailed comparison of CDases with regard to their substrate specificity and other biochemical properties.

\subsection{Acarbose hydrolysis}

Acarbose is a pseudotetrasaccharide that inhibits the activities of $\alpha$-amylases and $\alpha$-glucosidases. Acarbose hydrolysis is the unique feature of CDases, which convert acarbose into a pseudotrisaccharide and glucose [45]. However, in the presence of acarbose, cyclodextrinase activity of CDases may be inhibited possibly due to competition for access to the active site [22]. It has been reported that acarbose-mediated inhibition hinders the ring-opening of CDs [46]. CD-hydrolyzing MAase from Lactobacillus gasseri ATCC 33323 was completely inhibited by acarbose [32], while the MAase from Thermus sp. IM6501 (ThMA) and a cyclodextrinase from Streptococcus pyogenes could hydrolyse acarbose to glucose and acarviosineglucose. ThMA can further hydrolyze acarviosine-glucose into acarviosine and glucose [47,48]. A CDase from $L$. plantarum hydrolyzed acarbose via two different modes of action to produce maltose and acarviosine, as well as glucose and acarviosine-glucose [44].

\subsubsection{Transglycosylation}

CD-hydrolyzing enzymes also exhibit transglycosylation activity with various acceptor molecules mainly by creating different types of glucosidic linkages - $\alpha-1,3-, \alpha-1,4-$ and $\alpha-1,6$-glucosidic linkages, but $\alpha$-1,6-linkage is more common as seen in the case of CDases from Lactobacillus gasseri [32] and Streptococcus pyogenes [47]. ThMA transferred pseudotrisacharide obtained from acarbose hydrolysis to the C-6, C-3 and/or C-4 of the acceptors [45]. Similarly, a MAase from Bacillus thermoalkalophilus exhibited the $\alpha-1,3-, \alpha-1,4-$ and $\alpha-1,6-$ transferase activities [2]. The MAase from $B$. subtilis showed $\alpha-1,3$ - and $\alpha-1,6$-transferase activities only [14], whereas the archaeal MAase from Thermoplasma volcanium could form the $\alpha-1,4$ - and $\alpha-1,6$ linkages by transglycosylation [29]. Transglycosylation property of CDases has successfully been employed to synthesize several valuable compounds, such as branched oligosaccharides [49-51], carbohydrase inhibitors [52] and biologically active compounds, e.g. glycosyl-derivatives of ascorbic acid [4,53], puerarin [54], genistin [55] and simmondsin [48].

\subsection{Three dimensional structures of CDases}

CDases belong to family GH13 [56], and TAKA-amylase A (the $\alpha$-amylase from Aspergillus oryzae) was the first enzyme of this family whose three-dimensional structure was solved in 1984 [57]. The enzyme contains a $(\beta / \alpha)_{8}^{-}$ barrel catalytic domain, which consists of a barrel structure formed by eight $\alpha$-helices that surround eight parallel $\beta$-strands in a highly ordered manner. This $(\beta / \alpha)_{8}{ }^{-}$ 
Table 1: Biochemical properties and substrate specificity of CDases. ${ }^{a}$

\begin{tabular}{|c|c|c|c|c|c|c|c|}
\hline Organism & Temp. & $\mathrm{pH}$ & Substrate preference & Transglycosylation & $\mathrm{AH}$ & $\mathrm{CDH}$ & Ref. \\
\hline \multicolumn{8}{|l|}{ Bacteria } \\
\hline Thermus sp. IM6501 & 60 & 6 & $\beta-C D>$ Pullulan $>$ Starch & $\alpha-1,3, \alpha-1,4, \alpha-1,6$ & Yes & $M 1, M 2$ & [45] \\
\hline $\begin{array}{l}\text { Geobacillus } \\
\text { thermopakistaniensis }\end{array}$ & 55 & 6 & $\begin{array}{l}\alpha-C D>\beta-C D>\gamma-C D>\text { Dextrin }> \\
\text { Pullulan }>\text { Starch }\end{array}$ & Yes* $^{*}$ & Yes & $\mathrm{M} 1, \mathrm{M} 2$ & {$[22]$} \\
\hline Geobacillus sp. Gh6 & 60 & 6 & $\begin{array}{l}\alpha-C D>\beta-C D>\gamma-C D>\text { Amylose }> \\
\text { Amylopectin }>\text { Starch }>\text { Glycogen }\end{array}$ & ND & ND & ND & [35] \\
\hline Geobacillus thermoleovorans & 80 & $5-9$ & $\alpha-C D>\beta-C D>$ Starch $>$ Pullulan & Yes* & Yes & M2 & [73] \\
\hline $\begin{array}{l}\text { Bacillus thermoalkalophilus } \\
\text { ET2 }\end{array}$ & 70 & 8 & $\begin{array}{l}\beta-C D>\text { Maltotriose }>\text { Pullulan }> \\
\text { Starch }\end{array}$ & $\alpha-1,6, \alpha-1,4, \alpha-1,3$ & Yes & $M 1, M 2$ & [2] \\
\hline $\begin{array}{l}\text { Bacillus stearothermophilus } \\
\text { IMA6503 }\end{array}$ & 60 & 6 & $\beta-C D>$ Pullulan $\geq$ Starch & $\alpha-1,6, \alpha-1,4$ & Yes & $M 1, M 2$ & [108] \\
\hline $\begin{array}{l}\text { Bacillus stearothermophilus } \\
\text { HY-1 }\end{array}$ & 55 & 6 & $\beta-C D>$ Pullulan $\geq$ Starch & Yes* & Yes & $M 1, M 2$ & [34] \\
\hline Bacillus lehensis G1 & 40 & $7-9$ & $\beta-C D>S t a r c h$ & Yes* & ND & $\begin{array}{l}\text { M1, M2, } \\
\text { M3, MOS }\end{array}$ & {$[50]$} \\
\hline Bacillus clarkii & 30 & 8.5 & $\begin{array}{l}\gamma-C D>\text { Starch }>\beta-C D>\alpha-C D> \\
\text { Pullulan }=\text { Glycogen }\end{array}$ & Yes* & ND & $\mathrm{M} 2, \mathrm{MOS}$ & [17] \\
\hline $\begin{array}{l}\text { Geobacillus } \\
\text { caldoxylosilyticus TK4 }\end{array}$ & 50 & 7 & $\beta-C D>$ Starch & ND & ND & $\begin{array}{l}\text { M1, M2, } \\
\text { MOS }\end{array}$ & [19] \\
\hline Bacillus subtilis SUH4-2 & $40-45$ & 7 & $\beta-C D>$ Starch $>$ Pullulan & $\alpha-1,6, \alpha-1,3$ & Yes & $M 1, M 2$ & [14] \\
\hline Bacillus sp. US149 & 55 & 6.5 & $\beta-C D>$ Pullulan $>$ Starch & ND & ND & $M 1, M 2$ & [18] \\
\hline Bacillus sp. WPD616 & 50 & 6 & $\beta-C D>$ Pullulan $\geq$ Starch & ND & ND & ND & {$[21]$} \\
\hline $\begin{array}{l}\text { Anoxybacillus flavithermus } \\
\text { ZNU-NGA }\end{array}$ & 65 & 7 & $\begin{array}{l}\alpha-C D>\beta-C D>\gamma-C D>\text { Starch }= \\
\text { Glycogen }\end{array}$ & ND & ND & $\mathrm{M} 1, \mathrm{M} 2$ & [36] \\
\hline $\begin{array}{l}\text { Bacillus sphaericus ATCC } \\
7055\end{array}$ & 40 & $6-6.5$ & $\begin{array}{l}\beta-C D>\alpha-C D>\gamma-C D> \\
\text { Maltodextrins }\end{array}$ & ND & ND & $M 1, M 2$ & [16] \\
\hline Bacillus sphaericus E-244 & $>45$ & 8 & $\begin{array}{l}\beta-C D>\text { maltodextrins }>\alpha-C D> \\
\text { Starch }>\text { Pullulan }\end{array}$ & ND & ND & MOS & [10] \\
\hline Lactobacillus plantarum & 45 & 5 & $\beta-C D=$ Starch $>$ Pullulan & ND & Yes & M2 & [44] \\
\hline $\begin{array}{l}\text { Lactobacillus gasseri ATCC } \\
33323\end{array}$ & 55 & 5 & $\beta-C D>$ Pullullan $\geq$ Starch & ND & Yes & $M 1, M 2$ & [32] \\
\hline $\begin{array}{l}\text { Clostridium } \\
\text { thermohydrosulfuricum } 39 \mathrm{E}\end{array}$ & 65 & 5.9 & $\begin{array}{l}\alpha-C D>\beta-C D>\gamma-C D> \\
\text { Maltodextrins }>\text { Pullullan }>\text { Starch }\end{array}$ & ND & ND & M1 & {$[8,33]$} \\
\hline Bacillus coagulans & 50 & 6.2 & Maltodextrins $>\beta-C D>$ Starch & ND & ND & M2 & [7] \\
\hline Enterococcus faecium K-1 & 50 & 6 & $\alpha-C D>\beta-C D>$ Pullullan $>$ Starch & ND & ND & $M 1, M 2$ & {$[74]$} \\
\hline Massilia timonae CTI-57 & 40 & 7 & $\beta-C D>$ Maltodextrins $>$ Starch & ND & ND & $M 1, M 2$ & [20] \\
\hline Paenibacillus sp. A11 & 40 & 7 & $\begin{array}{l}\beta-C D>\gamma-C D>\alpha-C D> \\
\text { Maltodextrins }>\text { Starch }>\text { Pullulan }\end{array}$ & ND & ND & $\mathrm{M} 1, \mathrm{M} 2$ & {$[38,39]$} \\
\hline Flavobacterium sp. No. 92 & 30 & $6-7.5$ & $\begin{array}{l}\text { Maltodextrins }>\alpha-C D>\beta-C D> \\
\text { Starch }>\text { Pullullan }\end{array}$ & Yes* & ND & $\begin{array}{l}\text { M1, M2, } \\
\text { M3 }\end{array}$ & {$[15,61]$} \\
\hline $\begin{array}{l}\text { Alicyclobacillus } \\
\text { acidocaldarius }\end{array}$ & 55 & 5.5 & $\beta-C D>\alpha-C D>$ Starch $>$ Pullulan & ND & ND & ND & {$[40]$} \\
\hline
\end{tabular}


Table 1: Biochemical properties and substrate specificity of CDases. ${ }^{a}$

\begin{tabular}{|c|c|c|c|c|c|c|c|}
\hline Organism & Temp. & $\mathrm{pH}$ & Substrate preference & Transglycosylation & $\mathrm{AH}$ & $\mathrm{CDH}$ & Ref. \\
\hline Anoxybacillus flavithermus & 57.5 & 6.5 & $\begin{array}{l}\alpha-C D>\beta-C D>\text { Soluble Starch }> \\
\text { Amylose }>\text { Pullulan }\end{array}$ & ND & ND & ND & {$[41,69]$} \\
\hline Laceyella sacchari. & 57 & 6 & $\begin{array}{l}\beta-C D>\alpha-C D>\text { Amylose }>\text { Starch }> \\
\text { Pullulan }\end{array}$ & ND & ND & ND & {$[41,69]$} \\
\hline Streptococcus pyogenes & 45 & 7.5 & $\begin{array}{l}\beta-C D>\text { Maltotriose }>\text { Starch }> \\
\text { Pullulan }\end{array}$ & $\alpha-1,6$ & Yes & $M 1, M 2$ & {$[47]$} \\
\hline \multicolumn{8}{|l|}{ Archaea } \\
\hline Staphylothermus marinus & 100 & 5 & G6 $>$ Cycloamylose $>Y-C D$ & ND & Yes & $\mathrm{M} 1, \mathrm{M} 2$ & [30] \\
\hline $\begin{array}{l}\text { Thermoplasma volcanium } \\
\text { GSS1 }\end{array}$ & 80 & 5.5 & $\begin{array}{l}\text { Maltodextrins }>\beta-C D>\text { Starch }= \\
\text { Pullulan }\end{array}$ & $\alpha-1,4, \alpha-1,6$ & Yes & $\mathrm{M} 1, \mathrm{M} 2$ & [29] \\
\hline Pyrococcus furiosus & 90 & 4.5 & $\begin{array}{l}\alpha-C D>\beta-C D>\gamma-C D>\text { Maltotriose } \\
>\text { Pullulan }=\text { Starch }\end{array}$ & No & Yes & M7, MOS & {$[42]$} \\
\hline Thermofilum pendens & 95 & 5.5 & $\gamma-C D>\beta-C D>\alpha-C D>M D>P L=S S$ & ND & Yes & $M 1, M 2$ & {$[27]$} \\
\hline $\begin{array}{l}\text { Thermococcus sp. strain } \\
\text { B1001 }\end{array}$ & 95 & 5.5 & $\begin{array}{l}\beta-C D>\alpha-C D>\gamma-C D>\text { Dextrin }> \\
\text { Starch }\end{array}$ & ND & ND & $M 1, M 2$ & [23] \\
\hline Thermococcus sp. CL1 & 85 & 5 & $\begin{array}{l}\alpha-C D>\beta-C D>\gamma-C D>\text { Dextrin }> \\
\text { Starch }>\text { Pullulan }\end{array}$ & ND & Yes & $\mathrm{M} 1, \mathrm{M} 2$ & [24] \\
\hline Thermococcus kodakarensis & 65 & 7.5 & $\begin{array}{l}\beta-C D>\gamma-C D>\alpha-C D>\text { Pullulan }> \\
\text { Starch }\end{array}$ & ND & ND & M1 & {$[25]$} \\
\hline Palaeococcus pacificus & 95 & 6 & $\alpha-C D>\beta-C D>\gamma-C D>$ Starch & ND & ND & $M 1, M 2$ & [31] \\
\hline
\end{tabular}

${ }^{a}$ Temp. - temperature $\left({ }^{\circ} \mathrm{C}\right) ; \mathrm{AH}$ - acarbose hydrolysis; $\mathrm{CDH}$ - end products of cyclodextrin hydrolysis; Ref. - reference(s); * transglycosylation activity was detected but the type of newly created glucosidic linkages is not described; ND - not determined; M1 - glucose; M2 - maltose, M3 - maltotriose; M4 - maltotetraose; M6 - maltohexaose; M7 - maltoheptaose; M8 - maltooctaose; MOS maltooligosaccharides; MD - maltodextrins.

barrel domain was initially identified in triosephosphate isomerase, therefore also referred as TIM barrel domain. Later, this common folding scaffold was found in many enzymes from the GH13 family and now it is considered as a distinguishing feature of this family.

Three dimensional structures of several CDases have been solved. Among them, CDases from bacterial origin include Thermoactinomyces vulgaris R-47 [58], Thermus sp. IM6501 [59], Bacillus stearothermophilus [60] and Flavobacterium sp. no. 92 [61], while archaeal counterparts include Staphylothermus marinus [62] and Pyrococcus furiosus [28]. These structures reveal that, similar to typical $\alpha$-amylases, CDases are multi-domain enzymes and contain three basic domains (A, B and C). Domain A is the central core domain comprising the common catalytic $(\beta / \alpha)_{8}$-barrel. Domain B contains the most conserved aspartic acid residue and protrudes out of the $(\beta / \alpha)_{8}$ barrel as an insertion between $\beta 3$-strand and $\alpha 3$-helix. Domain $C$ is positioned after the $(\beta / \alpha)_{8}$-barrel $[56,63]$. In addition to these common domains, CDases possess one or two N-terminally located exceptional domains, which enable them to hydrolyze CDs (Fig. 1). Bacterial CDase contains a single $\mathrm{N}$-domain, which enables them to adopt a homodimeric configuration through interaction of the $\mathrm{N}$-domain of one subunit with the catalytic barrel domain of the other subunit (Fig. 2). As a result, a narrow and deep active site is generated, which is especially suitable for preferential accommodation of smaller substrates [3,58-60,62]. However, CDases from hyperthermophilic archeons contain an extra domain, the N'-domain, in addition to N-terminal domain, which swaps around its own active site (Fig. 2). In this way, the N'-domain helps the monomeric subunit of archaeal enzymes in creation of a narrow catalytic pocket, similar to the dimeric bacterial counterparts. Consequently, the monomeric CDases from hyperthermophilic archaea are believed to have acquired a novel domain configuration, with all structural components for recognition and cleavage of 
A

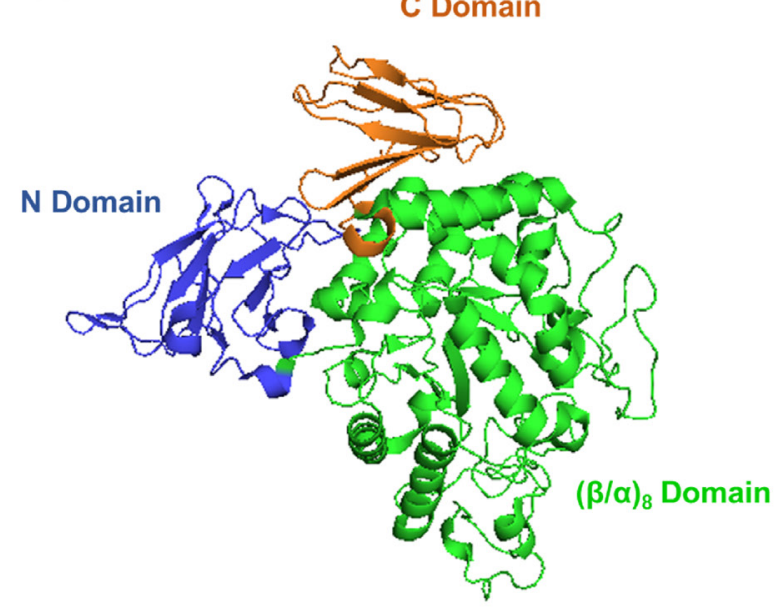

B

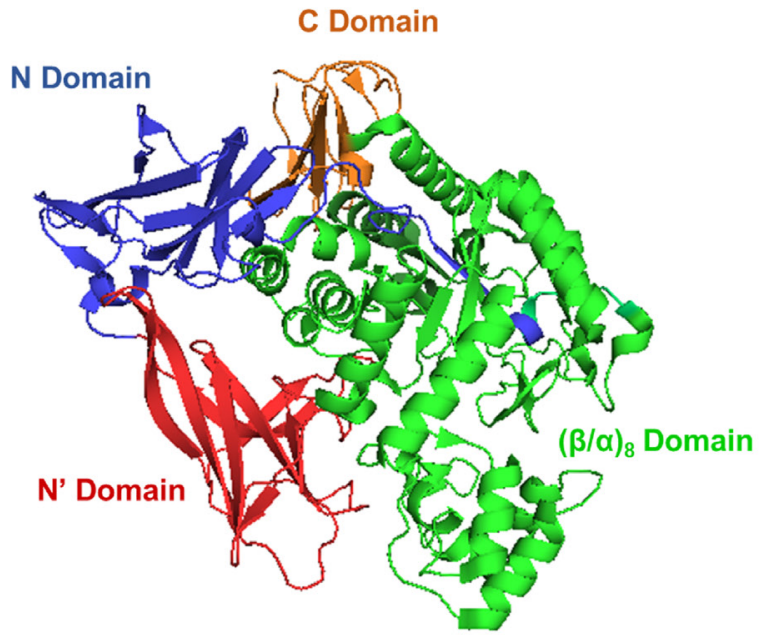

Figure 1: General domain organization in the tertiary structures of (A) bacterial (Thermus sp. IM6501; PDB: 1SMA) and (B) archaeal (Staphylothermus marinus; PDB: 4AEE) CDases. The N'-domain is absent in bacterial counterparts.
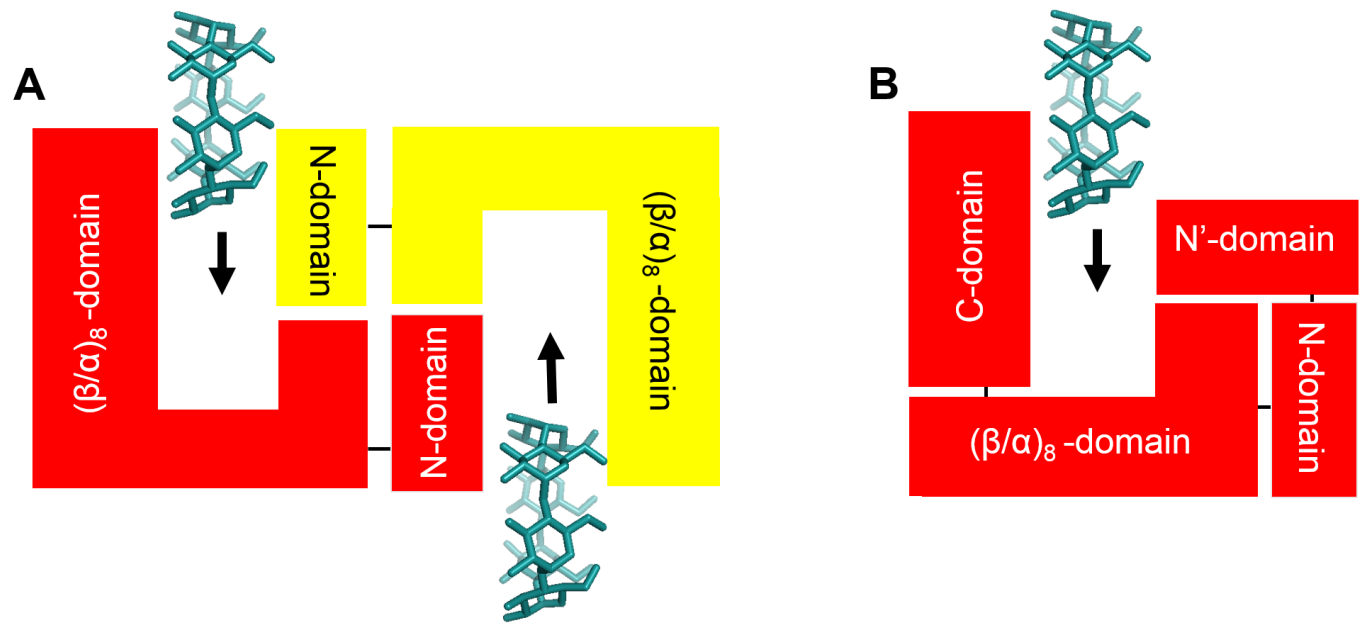

Figure 2: A schematic representation of active site pockets of bacterial (A) and archaeal (B) CDases as proposed by Kim et al. [59] and Jung et al. [62], respectively. The architecture of the active site is a narrow groove to fit in CDs.

the smaller substrates [28-30,62]. N-terminal domains of CDases are also known as starch-binding domains (SBD) and classified as carbohydrate binding module (CBM) families [56,64]. Bacterial N-domain is classified as family CBM34, while archaeal N'-domain is classified as CBM48. In the structure of archaeal CDases CBM48 always precedes the CBM34 at the N-terminus [56,64]. Owing to additional N-terminal domains and other similarities, most of the CD-hydrolyzing enzymes are grouped together in subfamily GH13_20 of the of the $\alpha$-amylase superfamily GH13. Some of them have also been placed in subfamilies GH13_36, GH13_21 and GH13_2 [64-66]. Subfamily GH13_20 was previously known as neopullulanase subfamily and have extensively been reviewed in terms of domain evolution, sequence and structural similarities [56].

\subsection{Physiological role}

CDases are involved in modulation of carbohydrate metabolism in bacteria [4,67]. Larger saccharides remain unable to cross the bacterial membranes and are converted to smaller subunits (maltose, maltodextrins or CDs) extracellularly with the help of amylases, 


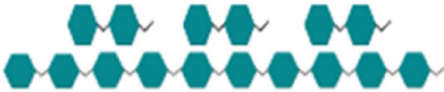
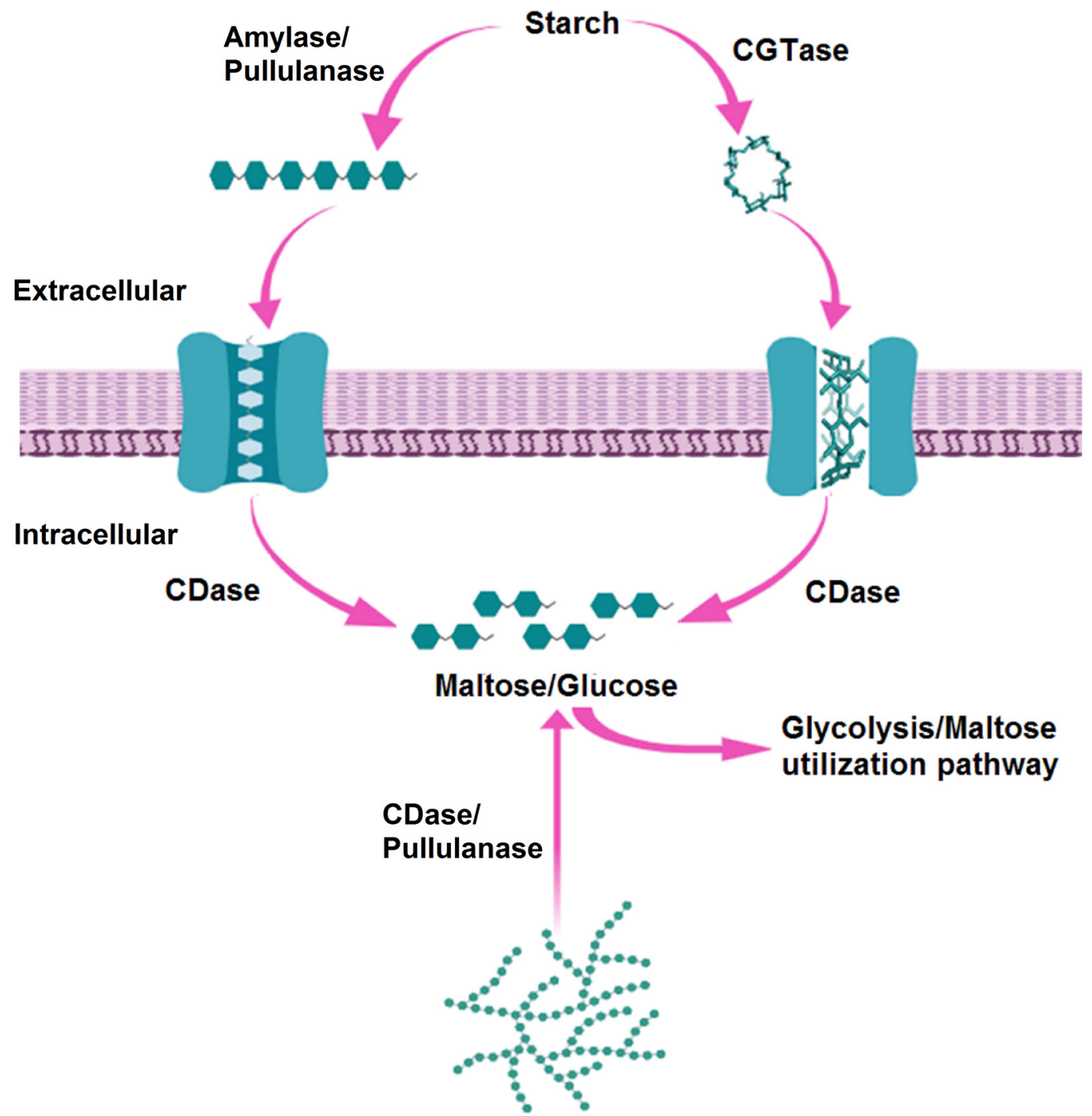

Glycogen

Figure 3: A schematic diagram showing the physiological role of CDases in carbohydrate metabolism in bacteria. Adapted and modified from Shim et al. [67].

pullulanases, cyclodextrin glycosyltransferases or other related enzymes. Maltose, maltodextrins and CDs thus produced are transferred to the cells, through facilitated diffusion, by specific transporters. After entering the cell, these molecules play their role in glucose metabolism or act as osmolytes. Based on previous studies on physiological roles of CDases in bacteria, a schematic illustration of the physiological role of these enzymes is shown in Figure 3.

\subsection{Oligomeric state}

Dimerization or oligomerization is a common physical property of proteins. It provides structural stability, increases enzyme activity by concentrating the active site, facilitates thermostability and helps to minimize genome size [68]. Oligomerization plays a unique role in the active-site formation of certain structurally known CDases [59]. In addition to stability, oligomeric state 


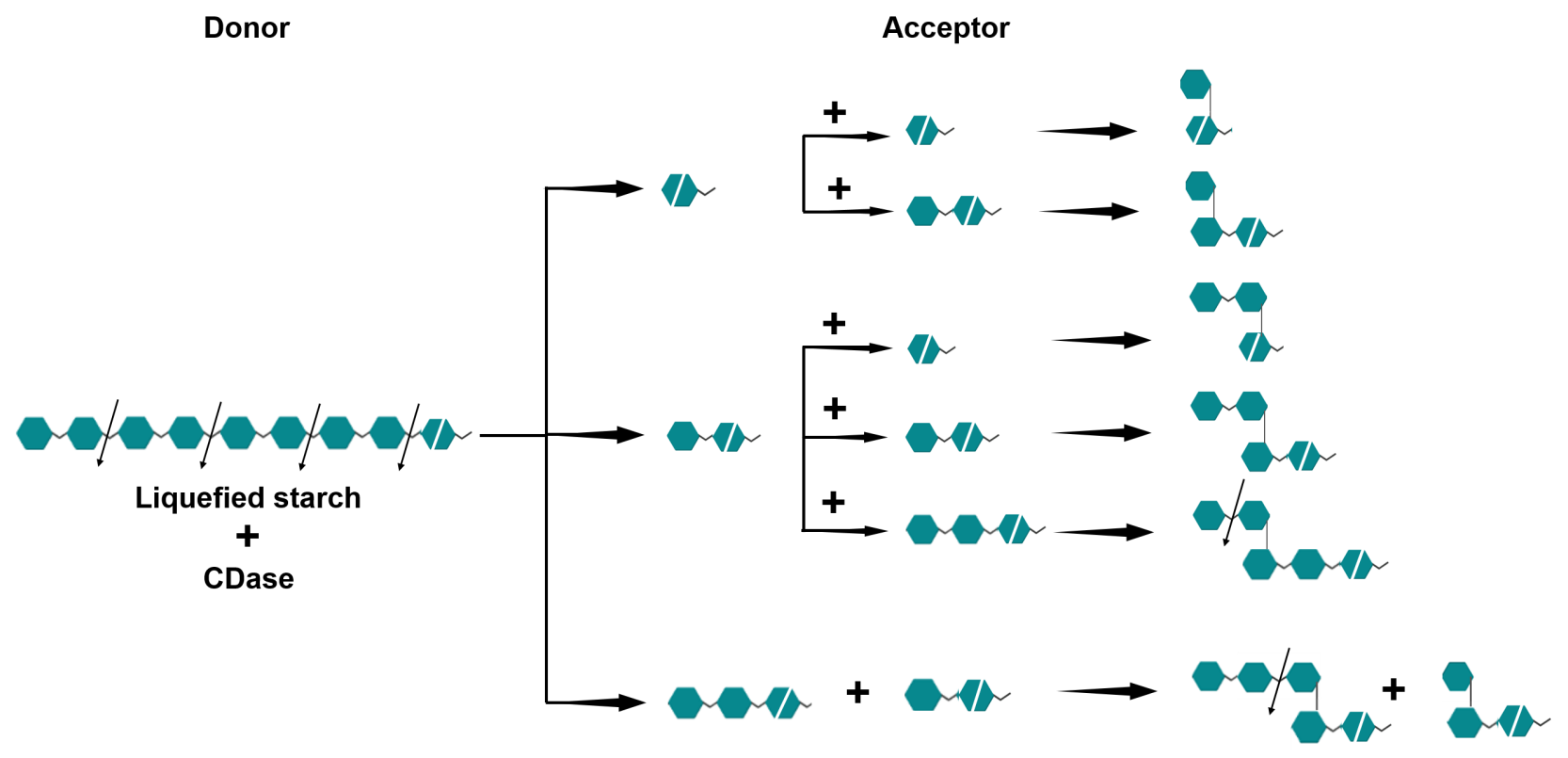

Figure 4: Schematic diagram showing the production of branched oligosaccharides by the action of CDases. Adapted and modified from Lee et al. [81] and Lee et al. [83]. Glucose residues are represented with filled hexagons, while crossed hexagons with overhangs are representing the reducing ends.

of CDases plays role in substrate preference $[41,69,70]$. Despite these facts, there are CDases that are monomeric in nature. The monomeric CDases include the enzymes from Paenibacillus sp. A11 [39] and Thermococcus sp. CL1 [24]. The CD-preferring hydrolase from Staphylothermus marinus is active in monomeric form, yet it forms a dimeric structure when studied using the X-ray crystallography [62]. The protein concentration may play a role in monomer to dimer formation. Most of the bacterial CDases exist in a dimeric or an oligomeric form. CDases from Bacillus licheniformis [71], Bacillus stearothermophilus ET1 [72], Thermus sp. IM6501 [45], Geobacillus thermoleovorans [73], Enterococcus faecium K-1 [74], Bacillus halodurans C-125 [75] and Pyrococcus furiosus [42] exist in dimeric form. CDases isolated from Massilia timonae, Lactobacillus gasseri ATCC 33323 and cow rumen metagenome showed tetrameric structures [20,32,43]. Similarly, CDases from alkalophilic Bacillus sp. I-5, Bacillus clarkii and Lactobacillus plantarum showed dodecameric assembly $[13,17$ 44]. CDase from Thermoplasma volcanium GSS1 existed in a higher oligomeric state, which dissociated into monomers and dimers in the presence of $1 \mathrm{M} \mathrm{NaCl}$. Moreover, the dissociated forms of this enzyme were less stable as compared to its native higher oligomeric form [29]. In a similar study, the ThMA dimeric molecule was found dissociating into monomeric one in the presence of
$1 \mathrm{M} \mathrm{KCl}$ [76]. ThMA, in the dimeric form, was more active for hydrolysis of $\beta$-CD, whereas the monomeric form preferred relatively large substrates, such as starch, although its overall activity was lower than that of the dimeric form $[29,76]$. In addition to enzyme activity, thermostability studies on CDase from Bacillus sp. I-5 revealed that oligomeric form was more stable than dimeric one [70].

\section{Applications of CDases}

\subsection{Production of branched oligosaccharides}

Branched maltooligosaccharides have importance in the food industry due to their properties of mild sweetness and low viscosity [49,77,78]. Isomaltooligosaccharides are beneficial for optimized intestinal and colon function. These are also known for antidiabetic effects and their role in improvement of lipid metabolism as well as obesity management $[79,80]$. Production of branched oligosaccharides/isomaltooligosaccharides can be achieved using coupled hydrolytic and transglycosylation activities exhibited by MAases/CDases (Fig. 4). A CDase from Bacillus lehensis proved to be a good candidate for the production of oligosaccharides by virtue of its 
high transglycosylation activity [50]. In addition to this enzyme, MAases from Lactobacillus gasseri [51], Bacillus licheniformis [81], Bacillus stearothermophilus [82, 83] and Bacillus subtilis [84] have also been employed for the production of branched oligosaccharides.

\subsection{Production of maltose syrup}

Maltose syrup finds wide applications in food industry as sweetener, humectant and preservative. High maltose syrups are categorized as a mixture of saccharides (glucose, maltose and oligosaccharides) having more than $70 \%$ maltose content. These syrups are used as substitute to glucose syrups in canning, bakery and confectionary, especially in the production of hard candies to manage stickiness, crystallization and glossiness [85]. These syrups are obtained from the enzymatic hydrolysis of starch. The traditional process involves starch liquefaction using thermostable $\alpha$-amylases, and saccharification using exo-amylases ( $\beta$-amylases) and debranching enzymes (pullulanases). The use of MAases showed superiority over $\beta$-amylases, resulting in enhanced yield of maltose content [86]. Maltose syrups with more than $90 \%$ maltose contents have successfully been produced employing variants of MAases from Bacillus stearothermophilus $[87,88]$.

\subsection{Antistaling agents for bakery products}

CD-preferring hydrolases, which produce maltose, maltotriose and maltotetraose, are reported to increase the shelf-life of bakery products by delaying retrogradation of starch [89,90]. Retrogradation occurs due to re-crystallization of amylose and amylopectin from gelatinized starch, and results in the hardness of bread crumb commonly known as bread staling. A thermostable maltogenic $\alpha$-amylase (Novamyl ${ }^{\circledR}$ ) from Bacillus sp. TS-25, formerly Bacillus stearothermophilus, is widely employed as an antistaling agent in the baking industry. Although this enzyme possesses a little endo-activity, it does act as an exo-enzyme during baking. It modifies starch at a temperature when it starts to gelatinize [91]. Novamyl ${ }^{\circledR}$ was initially of limited use as it was ineffective at lower $\mathrm{pH}$. Mutants of this enzyme with improved performance at low $\mathrm{pH}$ found applications in the production of sourdough and rye bread [92]. A few other MAases have also been employed recently to decrease the retrogradation and hardness of bread [91].

\subsection{Modification of rice starch}

CD-preferring hydrolases are being used to modify starch structure in order to produce low-amylose starch products. Rice starch incubated with alkalophilic Bacillus sp. I-5 CDase showed a decrease in amylose content from 28.5 to $9 \%$, while the amylopectin content remained almost unchanged. As a result, the modified rice starch showed a decreased rate of retrogradation when stored at $4{ }^{\circ} \mathrm{C}$ for 7 days [93]. Similarly, a thermostable MAase from Thermofilum pendens has been used to reduce the retrogradation of rice foods [94]. In addition to these enzymes, a NPase/CDase from Bacillus stearothermophilus TRS40 was able to selectively hydrolyze relatively small amylose molecules in the presence of large amylopectin molecules in starch. Such enzymes can be used to produce low-amylose starch [95].

\subsection{Production of carbohydrase inhibitors}

During the past couple of decades, carbohydrase inhibitors have gained the attention of physicians to manage disorders of carbohydrate metabolism, such as type 2 diabetes and ruminal acidosis [96]. In addition, the carbohydrase inhibitors can also be employed for uncovering the physiological roles of various glycans [97]. CDases have been utilized for the production and modification of these inhibitors. For example, acarbose, an inhibitor of several carbohydrases, has been modified by transglycosylation capability of CDases to give acarviosineglucose (4- $\alpha$-acarviosine-D-glucopyranose), isoacarbose (4n- $\alpha$-acarviosine isomaltose), $\quad 4-\alpha$-acarviosine- $6 n-\alpha$ glucopyranosyl cellobiose and 4- $\alpha$-acarviosine- $6^{\text {Gal }} \alpha-\alpha$-Dglucopyranosyl lactose. These analogues are found to be very potent and specific inhibitors of $\alpha$-amylases [52,98].

\subsection{Amylolytically-resistant starch}

Amylolytically-resistant starches are digested slowly in the small intestine, thereby consumed by beneficial gut microbiota in the colon. Due to this property, these resistant starches are often termed as prebiotics since they promote the growth of probiotics. Resistant starches are produced by modification of native starches through hydrolysis, transglycosylation and rearrangement of chain lengths and branch points [99]. Tapioca starch, extracted from roots of the cassava plant, is one of the most important carbohydrate food sources in many regions of the tropics. It has been modified using a branching enzyme and a 
MAase to produce highly branched and low molecular weight starch [100]. The resultant modified starch had decreased molecular weight, increased proportion of shorter branch chains, decreased proportion of longer branch chains, and thus decreased amylose content. Modified tapioca starch showed a slow hydrolysis rate by $\alpha$-amylases and glucoamylases. Such properties of modified starch ensure slow digestion, which is desirable during prolonged periods of exercise [99]. Enzymatic strategies to modify the structures of starch are expected to take over chemical methods soon [99], providing new routes towards healthy starches. Similar to these studies, treatment of pea starch with MAase and pullulanase resulted in decreased chain length and increased branch density of modified starch [101].

\subsection{Transglycosylation of ascorbic acid}

Ascorbic acid, a natural antioxidant, has been modified using transglycosylation activity of CDase from Bacillus stearothermophilus. Using maltotriose as donor molecule, 6-O-R-D-glucosyl- and 6-O-R-D-maltosyl-ascorbic acids have been synthesized from reaction of maltotriose and ascorbic acid (Fig. 5A). Similarly, 6-O-R-acarviosineD-glucosyl- and 2-O-R-acarviosine-D-glucosyl ascorbic acids have been synthesized in the transglycosylation reaction of ascorbic acid (as acceptor) and acarbose (as donor) [53]. Concerning oxidative stability, the 6-O-R-Dmaltosyl-ascorbic acid was found to be more stable than the ascorbic acid, while antioxidant effects of glycosylderivatives of ascorbic acid are similar to that of ascorbic acid [53].

\subsection{Glycosylation of biologically active compounds}

CDases have been employed for modification of several biologically active compounds to improve their properties. A few examples are described here.

Naringin, a flavonone glycoside, is one of the predominant bitter components present in grapefruit. In order to reduce bitterness and enhance solubility, narinigin has been modified using a CDase from Bacillus stearothermophilus. The resulting compound, maltosylnaringin (Fig. 5B), was 250-times more soluble in water and 10-times less bitter than the parent compound naringin [102].

Puerarin (daidzein 8-C-glucoside), an isoflavone is prescribed for coronary heart diseases, cardiac infarction, problems in ocular blood flow, sudden deafness, and alcoholism. However, puerarin cannot be given by injection due to its low solubility in water. In order to increase solubility, puerarin was transglycosylated (Fig. 5C). Glycosylation of puerarin using Bacillus stearothermophilus MAase enhanced the solubility up to 168 times as compared to that of unglycosylated puerarin [103]. Similarly, an archaeal CDase from Thermofilum pendens was employed for glycosylation of puerarin at high temperatures to ensure lower viscosity of solution and avoid contamination (Fig. 5D) [54]. In another study, a puerarin inclusion complex with cycloamylose was synthesized enzymatically using the MAase from Bacillus stearothermophilus and 4- $\alpha$-glucanotransferase from Thermus scotoductus. The encapsulated glycosylated puerarin was presumed to be widely applicable due to its improved water solubility and stability. Carbohydrateactive enzymes in the human intestine may readily digest the inclusion complex thus improving the bioavailability of puerarin [104].

Genistin, an isoflavone, with proven bioactive role within the neonatal intestine potentially reduces the severity of rotavirus infections. The CD-preferring hydrolase from archaeon Staphylothermus marinus has been employed to catalyze the genistin glycosylation using $y$-CD as glucosyl donor (Fig. 5E). The glycosylated genistins exhibited enhanced free radical scavenging capacity, indicating its increased antioxidant potential [55].

Erythritol, a four-carbon sugar alcohol, has been transglycosylated by using the MAase from Bacillus stearothermophilus (Fig. 5F). The resulting compound, maltosyl-erythritol, displayed quite less negative sensory properties and its sweetness was $40 \%$ to that of sugar [105].

\subsection{Production of maltodextrins}

CDases can be employed for the production of maltodextrins. The CDase from Pyrococcus furiosus has been reported to produce maltodextrins from $\beta$-CD. The enzyme immobilized in a packed-bed reactor produced maltohexaose and maltooctaose with $92 \%$ and $97 \%$ purity, respectively [106]. Another archaeal CDase from Palaeococcus pacificus was reported to produce high purity maltoheptaose from $\beta$-CD [31]. 
(O)

Maltotriose
$\overbrace{\mathrm{OHO}}^{\mathrm{HO}}$

Ascorbic Acid

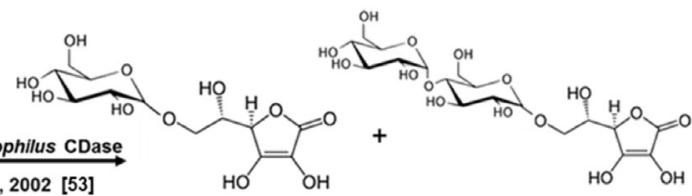

6-O-R-D-glucosyl-ascorbate

6-O-R-D-maltosyl-ascorbate

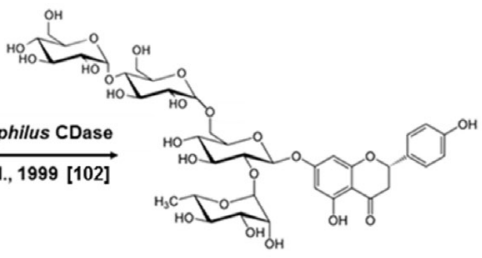

Maltosyl Naringin

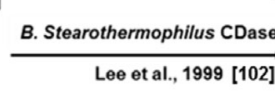

B

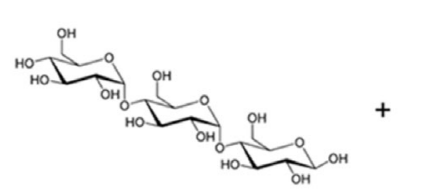

Maltotriose

Naringin

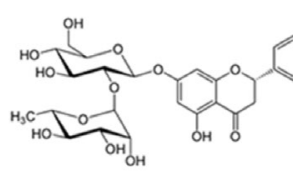

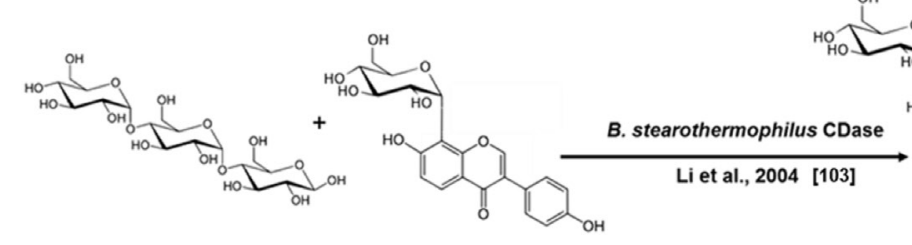

Maltotriose

Puerarin
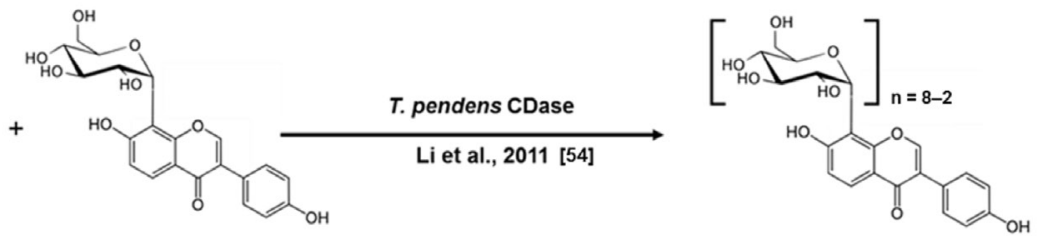

Glycosylated Puerarin

Puerarin

Beta-Cyclodextrin
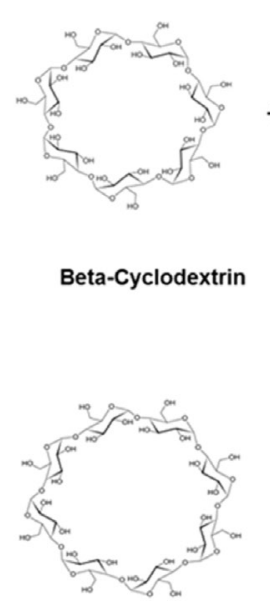

Gamma-Cyclodextrin

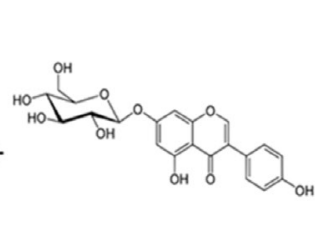

Genistin

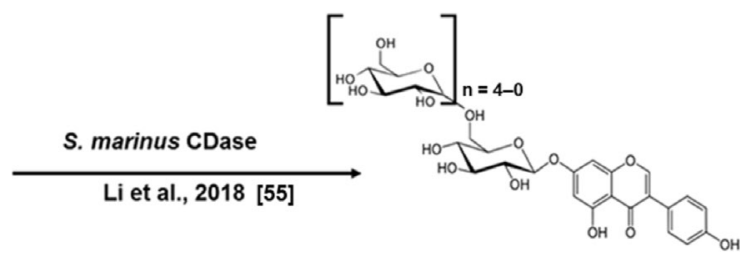

Glycosylated-Genistin<smiles></smiles>

Figure 5: Transglycosylation reactions catalysed by CDases for modification of biologically active compounds. 


\subsection{Recovery of cholesterol}

Nowadays, a rise in cardiac disorders attributed to high cholesterol levels is of significant clinical concern. Efforts have been made to reduce the cholesterol content of dairy products, such as cheese, butter and milk by using $\beta$-CD forming inclusion complexes. The resulting $\beta$-CDcholesterol complex can be treated with CDases to recover cholesterol [107].

\section{Conclusion}

In the present review we have tried to summarize the information available on the substrate specificity, structural features, physiological roles and applications of CD-preferring GHs. These enzymes form a distinct group in the $\alpha$-amylase family based on their structural features and substrate preferences. Multi-substrate specificity along with coupled hydrolytic and transglycosylation activities make these enzymes potential candidates for food and health sectors.

Conflict of interest: The authors declare no conflict of interest.

\section{References}

[1] Stam M.R., Danchin E.G.J., Rancurel C., Coutinho P.M., Henrissat B., Dividing the large glycoside hydrolase family 13 into subfamilies: towards improved functional annotations of $\alpha$-amylase-related proteins. Protein Eng. Des. Sel. 2006, 19, 555-562. https://doi.org/10.1093/protein/gzl044

[2] Cheong K.A., Tang S.Y., Cheong T.K., Cha H., Kim J.W., Park K.H., Thermostable and alkalophilic maltogenic amylase of Bacillus thermoalkalophilus ET2 in monomer-dimer equilibrium. Biocatal. Biotransform. 2005, 23, 79-87. https://doi. org/10.1080/10242420500090094

[3] Lee H.S., Kim M.S., Cho H.S., Kim J.I., Kim T.J., Choi J.H., et al., Cyclomaltodextrinase, neopullulanase, and maltogenic amylase are nearly indistinguishable from each other. J. Biol. Chem. 2002, 277, 21891-21897. https://doi.org/10.1074/jbc. M201623200

[4] Park K.H., Function and tertiary-and quaternary-structure of cyclodextrin-hydrolyzing enzymes (CDase), a group of multisubstrate specific enzymes belonging to the $\alpha$-amylase family. J. Appl. Glycosci. 2006, 53, 35-44. https://doi. org/10.5458/jag.53.35

[5] DePinto J.A., Campbell L.L., Purification and properties of the cyclodextrinase of Bacillus macerans. Biochemistry 1968, 7, 121-125. https://doi.org/10.1021/bi00841a016
[6] DePinto J.A., Campbell L.L., Pattern of action of the amylase and the cyclodextrinase of Bacillus macerans. Arch. Biochem. Biophys. 1968, 125, 253-258. https://doi.org/10.1016/00039861(68)90659-0

[7] Kitahata S., Taniguchi M., Beltran S.D., Sugimoto T., Okada S., Purification and some properties of cyclodextrinase from Bacillus coagulans. Agric. Biol. Chem. 1983, 47, 1441-1447. https://doi.org/10.1080/00021369.1983.10865801

[8] Saha B.C., Zeikus J.G., Characterization of thermostable cyclodextrinase from Clostridium thermohydrosulfuricum 39E. Appl. Environ. Microbiol. 1990, 56, 2941-2943. https:// doi.org/10.1128/AEM.56.9.2941-2943.1990.

[9] Yoshida A., Iwasaki Y., Akiba T., Horikoshi K., Purification and properties of cyclomaltodextrinase from alkalophilic Bacillus sp. J. Ferment. Bioeng. 1991, 71, 226-229. https://doi. org/10.1016/0922-338X(91)90272-I

[10] Oguma T., Kikuchi M., Mizusawa K., Purification and some properties of cyclodextrin-hydrolyzing enzyme from Bacillus sphaericus. Biochim. Biophys. Acta 1990, 1036, 1-5. https:// doi.org/10.1016/0304-4165(90)90205-b

[11] Oguma T., Kikuchi M., Mizusawa K., Some culture conditions for the production of cyclodextrin-hydrolyzing enzyme from Bacillus sphaericus. Agric. Biol. Chem. 1991, 55, 1661-1662. https://doi.org/10.1080/00021369.1991.10870838

[12] Oguma T., Matsuyama A., Kikuchi M., Nakano E., Cloning and sequence analysis of the cyclomaltodextrinase gene from Bacillus sphaericus and expression in Escherichia coli cells. Appl. Microbiol. Biotechnol. 1993, 39, 197-203. https://doi. org/10.1007/BF00228606

[13] Kim T.J., Shin J.H., Oh J.H., Kim M.J., Lee S.B., Ryu S., et al., Analysis of the gene encoding cyclomaltodextrinase from alkalophilic Bacillus sp. I-5 and characterization of enzymatic properties. Arch. Biochem. Biophys. 1998, 353, 221-227. https://doi.org/10.1006/abbi.1998.0639

[14] Cho H.Y., Kim Y.W., Kim T.J., Lee H.S., Kim D.Y., Kim J.W., et al., Molecular characterization of a dimeric intracellular maltogenic amylase of Bacillus subtilis SUH4-2. Biochim. Biophys. Acta 2000, 1478, 333-340. https://doi.org/10.1016/ s0167-4838(00)00037-6

[15] Bender H., Purification and characterization of a cyclodextrindegrading enzyme from Flavobacterium sp. Appl. Microbiol. Biotechnol. 1993, 39, 714-719. https://doi.org/10.1007/ BF00164455

[16] Galvin N., Kelly C., Fogarty W., Purification and properties of the cyclodextrinase of Bacillus sphaericus ATCC 7055. Appl. Microbiol. Biotechnol. 1994, 42, 46-50. https://doi. org/10.1007/BF00170223

[17] Nakagawa Y., Saburi W., Takada M., Hatada Y., Horikoshi K., Gene cloning and enzymatic characteristics of a novel Y-cyclodextrin-specific cyclodextrinase from alkalophilic Bacillus clarkii 7364. Biochim. Biophys. Acta 2008, 1784, 2004-2011. https://doi.org/10.1016/j.bbapap.2008.08.022

[18] Mabrouk S.B., Messaoud E.B., Ayadi D., Jemli S., Roy A., Mezghani M., et al., Cloning and sequencing of an original gene encoding a maltogenic amylase from Bacillus sp. US149 strain and characterization of the recombinant activity. Mol. Biotechnol. 2008, 38, 211-219. https://doi.org/10.1007/ s12033-007-9017-4

[19] Kolcuoglu Y., Colak A., Faiz O., Belduz A.O., Cloning, expression and characterization of highly thermo- and 
pH-stable maltogenic amylase from a thermophilic bacterium Geobacillus caldoxylosilyticus TK4. Process Biochem. 2010, 45, 821-828. https://doi.org/10.1016/j.procbio.2010.02.001

[20] Santos F.C.D., Barbosa-Tessmann I.P., Recombinant expression, purification, and characterization of a cyclodextrinase from Massilia timonae. Protein Expr. Purif. 2019, 154, 74-84. https://doi.org/10.1016/j.pep.2018.08.013

[21] Liu B., Wang Y., Zhang X., Characterization of a recombinant maltogenic amylase from deep sea thermophilic Bacillus sp. WPD616. Enzyme Microb. Technol. 2006, 39, 805-810. https://doi.org/10.1016/j.enzmictec.2006.01.003

[22] Aroob I., Ahmad N., Aslam M., Shaeer A., Rashid N., A highly active $\alpha$-cyclodextrin preferring cyclomaltodextrinase from Geobacillus thermopakistaniensis. Carbohydr. Res. 2019, 481, 1-8. https://doi.org/10.1016/j.carres.2019.06.004

[23] Hashimoto Y., Yamamoto T., Fujiwara S., Takagi M., Imanaka T., Extracellular synthesis, specific recognition, and intracellular degradation of cyclomaltodextrins by the hyperthermophilic archaeon Thermococcus sp. strain B1001. J. Bacteriol. 2001, 183, 5050-5057. https://doi.org/10.1128/jb.183.17.50505057.2001

[24] Lee J.E., Kim I.H., Jung J.H., Seo D.H., Kang S.G., Holden J.F., et al., Molecular cloning and enzymatic characterization of cyclomaltodextrinase from hyperthermophilic archaeon Thermococcus sp. CL1. J. Microbiol. Biotechnol. 2013, 23, 1060-1069. https://doi.org/10.4014/jmb.1302.02073

[25] Sun Y., Lv X., Li Z., Wang J., Jia B., Liu J., Recombinant cyclodextrinase from Thermococcus kodakarensis KOD1: expression, purification, and enzymatic characterization. Archaea 2015, 2015, 397924. https://doi. org/10.1155/2015/397924

[26] Ali R., Shafiq M.I., Sequence, structure, and binding analysis of cyclodextrinase (TK1770) from T. kodakarensis (KOD1) using an in silico approach. Archaea 2015, 2015, 179196. https:// doi.org/10.1155/2015/179196

[27] Li X., Li D., Yin Y., Park K.H., Characterization of a recombinant amylolytic enzyme of hyperthermophilic archaeon Thermofilum pendens with extremely thermostable maltogenic amylase activity. Appl. Microbiol. Biotechnol. 2010, 85, 1821-1830. https://doi.org/10.1007/s00253-0092190-6

[28] Park J.T., Song H.N., Jung T.Y., Lee M.H., Park S.G., Woo E.J., et al., A novel domain arrangement in a monomeric cyclodextrin-hydrolyzing enzyme from the hyperthermophile Pyrococcus furiosus. Biochim. Biophys. Acta 2013, 1834, 380-386. https://doi.org/10.1016/j.bbapap.2012.08.001

[29] Kim J.W., Kim Y.H., Lee H.S., Yang S.J., Kim Y.W., Lee M.H., et al., Molecular cloning and biochemical characterization of the first archaeal maltogenic amylase from the hyperthermophilic archaeon Thermoplasma volcanium GSS1. Biochim. Biophys. Acta 2007, 1774, 661-669. https://doi.org/10.1016/j. bbapap.2007.03.010

[30] Li D., Park J.T., Li X., Kim S., Lee S., Shim J.H., et al., Overexpression and characterization of an extremely thermostable maltogenic amylase, with an optimal temperature of $100^{\circ} \mathrm{C}$, from the hyperthermophilic archaeon Staphylothermus marinus. New Biotechnol. 2010, 27, 300-307. https://doi.org/10.1016/j.nbt.2010.04.001

[31] Ji H., Bai Y., Li X., Wang J., Xu X., Jin Z., Preparation of maltooligosaccharides with specific degree of polymerization by a novel cyclodextrinase from Palaeococcus pacificus. Carbohydr. Polym. 2019, 210, 64-72. https://doi. org/10.1016/j.carbpol.2019.01.041

[32] Oh K.W., Kim M.J., Kim H.Y., Kim B.Y., Baik M.Y., Auh J.H., et al., Enzymatic characterization of a maltogenic amylase from Lactobacillus gasseri ATCC 33323 expressed in Escherichia coli. FEMS Microbiol. Lett. 2005, 252, 175-181. https://doi. org/10.1016/j.femsle.2005.08.050

[33] Podkovyrov S.M., Zeikus J.G., Structure of the gene encoding cyclomaltodextrinase from Clostridium thermohydrosulfuricum $39 \mathrm{E}$ and characterization of the enzyme purified from Escherichia coli. J. Bacteriol. 1992, 174, 5400-5405. https://doi.org/10.1128/jb.174.16.54005405.1992

[34] Zhong W., Zheng Z.S., Jun Y.S., Purification and properties of cyclodextrinase from Bacillus stearothermophilus HY-1. Appl. Biochem. Biotechnol. 1996, 59, 63-75. https://doi. org/10.1007/BF02787858

[35] Nasrollahi S., Golalizadeh L., Sajedi R.H., Taghdir M., Asghari S.M., Rassa M., Substrate preference of a Geobacillus maltogenic amylase: a kinetic and thermodynamic analysis. Int. J. Biol. Macromol. 2013, 60, 1-9. https://doi. org/10.1016/j.ijbiomac.2013.04.063

[36] Aliakbari N., Mirzaee Z., Jafarian V., Khalifeh K., Salehi M., Genetic and biochemical characterization of a novel thermostable cyclomaltodextrinase from Anoxybacillus flavithermus. Starch 2019, 71, 1800133. https://doi. org/10.1002/star.201800133

[37] Tang K., Utairungsee T., Kanokratana P., Sriprang R., Champreda V., Eurwilaichitr L., et al., Characterization of a novel cyclomaltodextrinase expressed from environmental DNA isolated from Bor Khleung hot spring in Thailand. FEMS Microbiol. Lett. 2006, 260, 91-99. https://doi.org/10.1111/ j.1574-6968.2006.00308.x

[38] Kaulpiboon J., Pongsawasdi P., Purification and characterization of cyclodextrinase from Paenibacillus sp. A11. Enzyme Microb. Technol. 2005, 36, 168-175. https://doi. org/10.1016/j.enzmictec.2004.03.028

[39] Kaulpiboon J., Pongsawasdi P., Expression of cyclodextrinase gene from Paenibacillus sp. A11 in Escherichia coli and characterization of the purified cyclodextrinase. J. Biochem. Mol. Biol. 2004, 37, 408-415. https://doi.org/10.5483/ bmbrep.2004.37.4.408

[40] Matzke J., Herrmann A., Schneider E., Bakker E.P., Gene cloning, nucleotide sequence and biochemical properties of a cytoplasmic cyclomaltodextrinase (neopullulanase) from Alicyclobacillus acidocaldarius, reclassification of a group of enzymes. FEMS Microbiol. Lett. 2000, 183, 55-61. https://doi. org/10.1111/j.1574-6968.2000.tb08933.x

[41] Turner P., Labes A., Fridjonsson O.H., Hreggvidson G.O., Schönheit P., Kristjansson J.K., et al., Two novel cyclodextrindegrading enzymes isolated from thermophilic bacteria have similar domain structures but differ in oligomeric state and activity profile. J. Biosci. Bioeng. 2005, 100, 380-390. https://doi.org/10.1263/jbb.100.380

[42] Yang S.J., Lee H.S., Park C.S., Kim Y.R., Moon T.W., Park K.H., Enzymatic analysis of an amylolytic enzyme from the hyperthermophilic archaeon Pyrococcus furiosus reveals its novel catalytic properties as both an $\alpha$-amylase and a cyclodextrin-hydrolyzing enzyme. Appl. Environ. 
Microbiol. 2004, 70, 5988-5995. https://doi.org/10.1128/ AEM.70.10.5988-5995.2004

[43] Ferrer M., Beloqui A., Golyshina O.V., Plou F.J., Neef A., Chernikova T.N., et al., Biochemical and structural features of a novel cyclodextrinase from cow rumen metagenome. Biotechnol. J. 2007, 2, 207-213. https://doi.org/10.1002/ biot. 200600183

[44] Jang M.U., Kang H.J., Jeong C.K., Kang Y., Park J.E., Kim T.J., Functional expression and enzymatic characterization of Lactobacillus plantarum cyclomaltodextrinase catalyzing novel acarbose hydrolysis. J. Microbiol. 2018, 56, 113-118. https://doi.org/10.1007/s12275-018-7551-3

[45] Kim T.J., Kim M.J., Kim B.C., Kim J.C., Cheong T.K., Kim J.W., et al., Modes of action of acarbose hydrolysis and transglycosylation catalyzed by a thermostable maltogenic amylase, the gene for which was cloned from a Thermus strain. Appl. Environ. Microbiol. 1999, 65, 1644-1651. https:// doi.org/10.1128/AEM.65.4.1644-1651.1999

[46] Kim M.J., Park W.S., Lee H.S., Kim T.J., Shin J.H., Yoo S.H., et al., Kinetics and inhibition of cyclomaltodextrinase from alkalophilic Bacillus sp. I-5. Arch. Biochem. Biophys. 2000, 373, 110-115. https://doi.org/10.1006/abbi.1999.1471

[47] Jang M.U., Kang H.J., Jeong C.K., Oh G.W., Lee E.H., Son B.S., et al., Functional expression and enzymatic characterization of cyclomaltodextrinase from Streptococcus pyogenes. Korean J. Microbiol. 2017, 53, 208-215. https://doi.org/10.7845/ kjm.2017.7062

[48] Baek J.S., Kim H.Y., Abbott T.P., Moon T.W., Lee S.B., Park C.S., et al., Acarviosine-simmondsin, a novel compound obtained from acarviosine-glucose and simmondsin by Thermus maltogenic amylase and its in vivo effect on food intake and hyperglycemia. Biosci. Biotechnol. Biochem. 2003, 67, 532-539. https://doi.org/10.1271/bbb.67.532

[49] Ahmad R.A., Jaafar N.R., Manas N.H.A., Azelee N.I.W., Illias R.M., Nawawi N.N., Bioconversion of starch to maltooligosaccharides (MOS) by the reaction of maltogenic amylase. J. Teknologi 2020, 82, 99-105. https://doi. org/10.11113/jt.v82.14136

[50] Manas N.H.A., Pachelles S., Mahadi N.M., Illias R.M., The characterisation of an alkali-stable maltogenic amylase from Bacillus lehensis G1 and improved malto-oligosaccharide production by hydrolysis suppression. PLoS One 2014, 9, e106481. doi: https://10.1371/journal.pone.0106481

[51] Cho M.H., Park S.E., Lee M.H., Ha S.J., Kim H.Y., Kim M.J., et al., Extracellular secretion of a maltogenic amylase from Lactobacillus gasseri ATCC33323 in Lactococcus lactis MG1363 and its application on the production of branched maltooligosaccharides. J. Microbiol. Biotechnol. 2007, 17, 1521-1526.

[52] Robyt J.F., Park K.H., Lee S.B., Yoon S.H., Enzymatic synthesis of acarbose oligosaccharide analogues as new enzyme inhibitors. ACS Symp. Ser. 2003, 849, 161-181. https://doi. org/10.1021/bk-2003-0849.ch013

[53] Bae H.K., Lee S.B., Park C.S., Shim J.H., Lee H.Y., Kim M.J., et al., Modification of ascorbic acid using transglycosylation activity of Bacillus stearothermophilus maltogenic amylase to enhance its oxidative stability. J. Agric. Food Chem. 2002, 50, 3309-3316. https://doi.org/10.1021/jf011550z

[54] Li X., Li D., Park S.H., Gao C., Park K.H., Gu L., Identification and antioxidative properties of transglycosylated puerarins synthesised by an archaeal maltogenic amylase. Food Chem. 2011, 124, 603-608. https://doi.org/10.1016/j. foodchem.2010.06.082

[55] Li X., Wang Y., Park J.T., Gu L., Li D., An extremely thermostable maltogenic amylase from Staphylothermus marinus: Bacillus expression of the gene and its application in genistin glycosylation. Int. J.. Biol Macromol. 2018, 107, 413-417. https://doi.org/10.1016/j.ijbiomac.2017.09.007

[56] Kuchtova A., Janecek S., Domain evolution in enzymes of the neopullulanase subfamily. Microbiology 2016, 162, 20992115. https://doi.org/10.1099/mic.0.000390

[57] Matsuura Y., Kusunoki M., Harada W., Kakudo M., Structure and possible catalytic residues of Taka-amylase A. J. Biochem. 1984, 95, 697-702. https://doi.org/10.1093/oxfordjournals. jbchem.a134659

[58] Kamitori S., Kondo S., Okuyama K., Yokota T., Shimura Y., Tonozuka T., et al., Crystal structure of Thermoactinomyces vulgaris R-47 $\alpha$-amylase II (TVAII) hydrolyzing cyclodextrins and pullulan at 2.6 ̊̊ resolution. J. Mol. Biol. 1999, 287, 907-921. https://doi.org/10.1006/jmbi.1999.2647

[59] Kim J.S., Cha S.S., Kim H.J., Kim T.J., Ha N.C., Oh S.T., et al., Crystal structure of a maltogenic amylase provides insights into a catalytic versatility. J. Biol. Chem. 1999, 274, 2627926286. https://doi.org/10.1074/jbc.274.37.26279

[60] Hondoh H., Kuriki T., Matsuura Y., Three-dimensional structure and substrate binding of Bacillus stearothermophilus neopullulanase. J. Mol. Biol. 2003, 326, 177-188. https://doi. org/10.1016/s0022-2836(02)01402-x

[61] Fritzsche H.B., Schwede T., Schulz G.E., Covalent and three-dimensional structure of the cyclodextrinase from Flavobacterium sp. no. 92. Eur. J. Biochem. 2003, 270, 23322341. https://doi.org/10.1046/j.1432-1033.2003.03603.x

[62] Jung T.Y., Li D., Park J.T., Yoon S.M., Tran P.L., Oh B.H., et al., Association of novel domain in active site of archaic hyperthermophilic maltogenic amylase from Staphylothermus marinus. J. Biol. Chem. 2012, 287, 7979-7989. https://doi. org/10.1074/jbc.M111.304774

[63] Ahmad N., Mehboob S., Rashid N., Starch-processing enzymes - emphasis on thermostable 4- $\alpha$-glucanotransferases. Biologia 2015, 70, 709-725. https://doi.org/10.1515/biolog2015-0087

[64] Lombard V., Golaconda Ramulu H., Drula E., Coutinho P.M., Henrissat B., The carbohydrate-active enzymes database (CAZy) in 2013. Nucleic Acids Res. 2014, 42, D490-D495. https://doi.org/10.1093/nar/gkt1178

[65] Oslancova A., Janecek S., Oligo-1,6-glucosidase and neopullulanase enzyme subfamilies from the $\alpha$-amylase family defined by the fifth conserved sequence region. Cell. Mol. Life Sci. 2002, 59, 1945-1959. https://doi.org/10.1007/ pl00012517

[66] Cockburn D.W., Cerqueira F.M., Bahr C., Koropatkin N.M., The structures of the GH13_36 amylases from Eubacterium rectale and Ruminococcus bromii reveal subsite architectures that favor maltose production. Amylase 2020, 4, 24-44. https:// doi.org/10.1515/amylase-2020-0003

[67] Shim J.H., Park J.T., Hong J.S., Kim K.W., Kim M.J., Auh J.H., et al., Role of maltogenic amylase and pullulanase in maltodextrin and glycogen metabolism of Bacillus subtilis 168. J. Bacteriol. 2009, 191, 4835-4844. https://doi. org/10.1128/JB.00176-09 
[68] Marianayagam N.J., Sunde M., Matthews J.M., The power of two: protein dimerization in biology. Trends Biochem. Sci. 2004, 29, 618-625. https://doi.org/10.1016/j. tibs.2004.09.00

[69] Turner P., Nilsson C., Svensson D., Holst O., Gorton L., Karlsson E.N., Monomeric and dimeric cyclomaltodextrinases reveal different modes of substrate degradation. Biologia 2005, 60 (Suppl. 16), 79-87.

[70] Lee H.S., Kim J.S., Shim K.H., Kim J.W., Park C.S., Park K.H., Quaternary structure and enzymatic properties of cyclomaltodextrinase from alkalophilic Bacillus sp. I-5. Biologia 2005, 60 (Suppl. 16), 73-77.

[71] Kim I.C., Cha J.H., Kim J.R., Jang S.Y., Seo B.C., Cheong T.K., et al., Catalytic properties of the cloned amylase from Bacillus licheniformis. J. Biol. Chem. 1992, 267, 22108-22114. https:// doi.org/10.1016/S0021-9258(18)41642-0

[72] Cha H.J., Yoon H.G., Kim Y.W., Lee H.S., Kim J.W., Kweon K.S., et al., Molecular and enzymatic characterization of a maltogenic amylase that hydrolyzes and transglycosylates acarbose. Eur. J. Biochem. 1998, 253, 251-262. https://doi.org/10.1046/ j.1432-1327.1998.2530251.x

[73] Mehta D., Satyanarayana T., Dimerization mediates thermoadaptation, substrate affinity and transglycosylation in a highly thermostable maltogenic amylase of Geobacillus thermoleovorans. PLoS One 2013, 8, e73612. https://doi. org/10.1371/journal.pone.0073612

[74] Unban K., Kanpiengjai A., Lumyong S., Nguyen T.H., Haltrich D., Khanongnuch C., Molecular structure of cyclomaltodextrinase derived from amylolytic lactic acid bacterium Enterococcus faecium K-1 and properties of recombinant enzymes expressed in Escherichia coli and Lactobacillus plantarum. Int. J. Biol. Macromol. 2018, 107, 898-905. https://doi. org/10.1016/j.ijbiomac.2017.09.060

[75] Kang H.J., Jeong C.K., Jang M.U., Choi S.H., Kim M.H., Ahn J.B., et al., Expression of cyclomaltodextrinase gene from Bacillus halodurans C-125 and characterization of its multisubstrate specificity. Food Sci. Biotechnol. 2009, 18, 776-781.

[76] Kim T.J., Nguyen V.D., Lee H.S., Kim M.J., Cho H.Y., Kim Y.W., et al., Modulation of the multisubstrate specificity of Thermus maltogenic amylase by truncation of the $\mathrm{N}$-terminal domain and by a salt-induced shift of the monomer/dimer equilibrium. Biochemistry 2001, 40, 14182-14190. https:// doi.org/10.1021/bi015531u

[77] Nawawi N.N., Hashim Z., Rahman R.A., Murad A.M.A., Bakar F.D.A., Illias R.M., Entrapment of porous cross-linked enzyme aggregates of maltogenic amylase from Bacillus lehensis G1 into calcium alginate for maltooligosaccharides synthesis. Int. J. Biol. Macromol. 2020, 150, 80-89. https://doi. org/10.1016/j.ijbiomac.2020.02.032

[78] Yoo S.H., Kweon M.R., Kim K.J., Auh J.H., Jung D.S., Kim J.R., et al., Branched oligosaccharides concentrated by yeast fermentation and effectiveness as a low sweetness humectant. Food Sci. J. 1995, 60, 516-521. https://doi. org/10.1111/j.1365-2621.1995.tb09816.x

[79] Patel S., Goyal A., Functional oligosaccharides: production, properties and applications. World J. Microbiol. Biotechnol. 2011, 27, 1119-1128. https://doi.org/10.1007/s11274-0100558-5

[80] Candela M., Maccaferri S., Turroni S., Carnevali P., Brigidi P., Functional intestinal microbiome, new frontiers in prebiotic design. Int. J. Food Microbiol. 2010, 140, 93-101. https://doi. org/10.1016/j.ijfoodmicro.2010.04.017

[81] Lee S.J., Yoo S.H., Kim M.J., Kim J.W., Seok H.M., Park $\mathrm{KH}$., Production and characterization of branched oligosaccharides from liquefied starch by the action of Bacillus licheniformis amylase. Starch 1995, 47, 127-134. https://doi.org/10.1002/star.19950470403

[82] Kang G.J., Kim M.J., Kim J.W., Park K.H., Immobilization of thermostable maltogenic amylase from Bacillus stearothermophilus for continuous production of branched oligosaccharides. J. Agric. Food Chem. 1997, 45, 4168-4172. https://doi.org/10.1021/jf970378p

[83] Lee H.S., Auh J.H., Yoon H.G., Kim M.J., Park J.H., Hong S.S., et al., Cooperative action of $\alpha$-glucanotransferase and maltogenic amylase for an improved process of isomaltooligosaccharide (IMO) production. J. Agric. Food Chem. 2002, 50, 2812-2817. https://doi.org/10.1021/ jf011529y

[84] Kuriki T., Yanase M., Takata H., Takesada Y., Imanaka T., Okada S., A new way of producing isomalto-oligosaccharide syrup by using the transglycosylation reaction of neopullulanase. Appl. Environ. Microbiol. 1993, 59, 953-959. https://doi. org/10.1128/AEM.59.4.953-959.1993

[85] Hull P., Glucose Syrups: Technology and Applications. WileyBlackwell, 2010.

[86] Outtrup H., Norman B., Properties and application of a thermostable maltogenic amylase produced by a strain of Bacillus modified by recombinant-DNA techniques. Starch 1984, 36, 405-411. https://doi.org/10.1002/ star.19840361202

[87] Sun Y., Duan X., Wang L., Wu J., Enhanced maltose production through mutagenesis of acceptor binding subsite +2 in Bacillus stearothermophilus maltogenic amylase. J. Biotechnol. 2016, 217, 53-61. https://doi.org/10.1016/j. jbiotec.2015.11.007

[88] Shieh M., Barker P., Saccharification of modified starch to maltose in a semi-continuous counter-current chromatographic reactor-separator (SCCR-S). J. Chem. Technol. Biotechnol. 1995, 63, 125-134. https://doi. org/10.1002/jctb. 280630206

[89] Park S.H., Na Y., Kim J., Kang S.D., Park K.H., Properties and applications of starch modifying enzymes for use in the baking industry. Food Sci. Biotechnol. 2018, 27, 299-312. https://doi.org/10.1007/s10068-017-0261-5

[90] Haghighat-Kharazi S., Kasaai M.R., Milani J.M., Khajeh K., Optimization of encapsulation of maltogenic amylase into a mixture of maltodextrin and beeswax and its application in gluten-free bread. J. Texture Stud. 2020, 51, 631-641. https:// doi.org/10.1111/jtxs.12516

[91] Christophersen C., Otzen D.E., Noman B.E., Christensen S., Schäfer T., Enzymatic characterisation of Novamyl®, a thermostable $\alpha$-amylase. Starch 1998, 50, 39-45. https:// doi.org/10.1002/(SICI)1521-379X(199801)50:1<39::AIDSTAR39>3.0.CO;2-S

[92] Jones A., Lamsa M., Frandsen T.P., Spendler T., Harris P., Sloma A., et al., Directed evolution of a maltogenic $\alpha$-amylase from Bacillus sp. TS-25. J. Biotechnol. 2008, 134, 325-333. https:// doi.org/10.1016/j.jbiotec.2008.01.016

[93] Auh J.H., Chae H.Y., Kim Y.R., Shim K.H., Yoo S.H., Park K.H., Modification of rice starch by selective degradation of 
amylose using alkalophilic Bacillus cyclomaltodextrinase. J. Agric. Food Chem. 2006, 54, 2314-2319. https://doi. org/10.1021/jf051887r

[94] Li X., Li D., Tian H., Park K.H., Reducing retrogradation of gelatinized rice starch and rice meal under low temperature storage by addition of extremely thermostable maltogenic amylase during their cooking. Int. Food Res. J. 2014, 62, 1134-1140. https://doi.org/10.1016/j.foodres.2014.05.071

[95] Kamasaka H., Sugimoto K., Takata H., Nishimura T., Kuriki T., Bacillus stearothermophilus neopullulanase selective hydrolysis of amylose to maltose in the presence of amylopectin. Appl. Environ. Microbiol. 2002, 68, 1658-1664. https://doi.org/10.1128/aem.68.4.1658-1664.2002

[96] Marchesini G., De Nardi R., Ricci R., Andrighetto I., Serva L., Segato S., Effects of carbohydrase-inhibiting compounds on in vitro rumen fermentation. Ital. J. Anim. Sci. 2014, 13, 3264. https://doi.org/10.4081/ijas.2014.3264

[97] Gloster T.M., Vocadlo D.J., Developing inhibitors of glycan processing enzymes as tools for enabling glycobiology. Nat. Chem. Biol. 2012, 8, 683-694. https://doi.org/10.1038/ nchembio.1029

[98] Kim M.J., Lee S.B., Lee H.S., Lee S.Y., Baek J.S., Kim D., et al., Comparative study of the inhibition of $\alpha$-glucosidase, $\alpha$-amylase, and cyclomaltodextrin glucanosyltransferase by acarbose, isoacarbose, and acarviosine-glucose. Arch. Biochem. Biophys. 1999, 371, 277-283. https://doi. org/10.1006/abbi.1999.1423

[99] van der Maarel M.J., Leemhuis H., Starch modification with microbial $\alpha$-glucanotransferase enzymes. Carbohydr. Polym. 2013, 93, 116-121. https://doi.org/10.1016/j. carbpol.2012.01.065

[100] Le Q.T., Lee C.K., Kim Y.W., Lee S.J., Zhang R., Withers S.G., et al., Amylolytically-resistant tapioca starch modified by combined treatment of branching enzyme and maltogenic amylase. Carbohydr. Polym. 2009, 75, 9-14. https://doi. org/10.1016/j.carbpol.2008.06.001

[101] Liu P., Gao W., Zhang X., Wu Z., Yu B., Cui B., Physicochemical properties of pea starch-lauric acid complex modified by maltogenic amylase and pullulanase. Carbohydr. Polym. 2020, 242, 116332. https://doi.org/10.1016/j. carbpol.2020.116332

[102] Lee S.J., Kim J.C., Kim M.J., Kitaoka M., Park C.S., Lee S.Y., et al., Transglycosylation of naringin by Bacillus stearothermophilus maltogenic amylase to give glycosylated naringin. J. Agric. Food Chem. 1999, 47, 3669-3674. https:// doi.org/10.1021/jf990034u

[103] Li D., Park S.H., Shim J.H., Lee H.S., Tang S.Y., Park C.S., et al., In vitro enzymatic modification of puerarin to puerarin glycosides by maltogenic amylase. Carbohydr. Res. 2004, 339, 2789-2797. https://doi.org/10.1016/j. carres.2004.09.017

[104] Choi C.H., Kim J.W., Park C.S., Park K.H., Kyung M.O., Park J.T., et al., Enzymatic biosynthesis of a puerarin-cycloamylose inclusion complex by 4- $\alpha$-glucanotransferase and maltogenic amylase. Biocatal. Biotransform. 2010, 28, 209-214. https:// doi.org/10.3109/10242421003754538

[105] Yoon J.W., Jeon E.J., Jung I.H., Min M.J., Lee H.Y., Kim M.J., et al., Maltosyl-erythritol, a major transglycosylation product of erythritol by Bacillus stearothermophilus maltogenic amylase. Biosci. Biotechnol. Biochem. 2003, 67, 525-531. https://doi.org/10.1271/bbb.67.525

[106] Cuong N.P., Lee W.H., Oh I.N., Thuy N.M., Kim D.G., Park J.T., et al., Continuous production of pure maltodextrin from cyclodextrin using immobilized Pyrococcus furiosus thermostable amylase. Process Biochem. 2016, 51, 282-287. https://doi.org/10.1016/j.procbio.2015.11.022

[107] Kwon H.J., Jung H.J., Kwak H.S., Recovery of cholesterol from the $\beta$-cyclodextrin-cholesterol complex using immobilized cyclomaltodextrinase of alkalophilic Bacillus sp. KJ 133. J. Microbiol. Biotechnol. 2001, 11, 712-715.

[108] Cheong K.A., Kim T.J., Yoon J.W., Park C.S., Lee T.S., Kim Y.B., et al., Catalytic activities of intracellular dimeric neopullulanase on cyclodextrin, acarbose and maltose. Biotechnol. Appl. Biochem. 2002, 35, 27-34. https://doi. org/10.1042/BA20010052 